\title{
Antioxidant Properties of Lotus Leaf (Nelumbo nucifera) Powder and Barley Leaf (Hordeum vulgare) Powder in Raw Minced Pork during Chilled Storage
}

\author{
Ju-Hui Choe, Ji-Hun Choi ${ }^{1}$, Yun-Sang Choi ${ }^{1}$, Doo-Jeong Han, Hack-Youn Kim, Mi-Ai Lee, \\ Si-Young Kim, and Cheon-Jei Kim* \\ Department of Food Science and Biotechnology of Animal Resources, Konkuk University, Seoul 143-701, Korea \\ ${ }^{1}$ Research Institute for Meat Science and Culture, Konkuk University, Seoul 143-701, Korea
}

\begin{abstract}
The effects of additions of lotus leaf $(0.1$ and $0.5 \%)$ and barley leaf powder $(0.1$ and $0.5 \%)$ on the lipid oxidation and microbiological analysis of raw minced pork were investigated after $1,4,7$, and $10 \mathrm{~d}$ at chilled storage. Days of storage caused $(p<0.05)$ decreases in $\mathrm{pH}$ values in samples with lotus leaf (LP) and barley leaf powder (BP). $\mathrm{L}^{*}$ and a* values decreased, and $b^{*}$ values increased in the treatments with increasing lotus leaf and barley leaf powder contents, respectively. The decrease in a * values was lowest $(p<0.05)$ in the treatment with $0.1 \%$ BP. Thiobarbituric acid reaction substance values and free fatty acids in $0.5 \%$ LP were lowest $(p<0.05)$ on day 10 . Thus, the addition of lotus leaf powder significantly improved lipid oxidative stability in the raw minced pork during chilled storage of $10 \mathrm{~d}$. Furthermore, the raw minced pork treatments with LP and BP presented low peroxide values and total microbes as compared to control (-) (without LP and $\mathrm{BP})$. These results indicate that LP and BP can be incorporated into raw minced pork as natural additives to retard oxidation.
\end{abstract}

Key words: lotus leaf, barley leaf, lipid oxidation, microbiological analysis, minced pork

\section{Introduction}

Minced pork has become an important food due to its convenience. Minced meat is markedly changed by exposing lipid membranes to metal ions. This process makes possible the generation of free radicals and propagation of oxidative reactions by interacting pro-oxidants and unsaturated fatty acids (Asghar et al., 1988). Oxidative reactions in meat during processing and storage result in deteriorations of color, sensory quality, and decreased shelf-life. Therefore, it is important for the meat food industry to inhibit lipid oxidation in minced meat.

Antioxidants that have oxidative stability and enhance the quality of meat can be classified into two groups: synthetic antioxidants and natural antioxidants (Huber et al., 1995). Synthetic antioxidants such as butylated hydroxytoluene (BHT), butylated hydroxylanisole (BHA), tertbutylhydroquinone (TBHQ), and propyl gallate have been

\footnotetext{
*Corresponding author: Cheon-Jei Kim, Department of Food Science and Biotechnology of Animal Resources, Konkuk University, Seoul 143-701, Korea. Tel: 82-2-450-3684; Fax: 82-2-444-6695, E-mail: kimcj@konkuk.ac.kr
}

used in raw and precooked meat products as strong oxidative inhibitors. However, negative health effects of synthetic antioxidants have decreased their use (Shahidi et al., 1992). For example, high concentrations of BHT can be toxic (De Oliveira et al., 2009). These negative effects of synthetic antioxidants have led to interest in natural antioxidants due to their safety (Han and Lee, 2005). Natural antioxidants obtained from natural sources such as seeds, rinds, leaves, nuts of plants, honey, fruits, and vegetables have been studied for their antioxidant activities in meat products (Devatkal and Naveena, 2010; Naveena et al., 2008). Several studies have documented the antioxidant effects of grape seed extracts in chicken thigh meat (Brannan, 2008), kinnow rind and pomegranate rind extracts in goat meat patties (Devatkal and Narsaiah, 2010), and green tea leaf extracts in turkey sausages (Bozkurt, 2006). In recent studies, Bastida et al. (2009) observed the antioxidant activities of carob fruit extracts in pork meats, and Ganhão et al. (2010) reported on antioxidant activities of fruit extracts in burger patties.

Plant extracts containing phenolic compounds retard lipid oxidation in meat products by radical scavenging and metal-chelating activities (Rice-Evans et al., 1996). 
Lotus (Nelumbo nucifera) leaf has antioxidant compounds such as phenolic acids and flavonoids (Choe et al., 2010). Several studies have reported on the antioxidant effects (Choe et al., 2010; Lee et al., 2006a) and antimicrobial activities (Lee et al., 2006b) of lotus leaf extracts. In addition, lotus leaf has been used as a functional food because of its various biologically active components (Lee et al., 2006). For example, lotus leaf powder was added to sulgitteok (Yoon, 2007) and fish paste (Shin, 2007).

Interest in the functionality of barley leaf, which contains the natural antioxidant enzyme superoxide dismutase (SOD), vitamin $\mathrm{C}$, vitamin $\mathrm{E}, \beta$-carotene, and flavonoids, has increased (Arimoto et al., 2000). Lee et al. (1994) studied the antioxidant activity of barley leaf extract and Jang et al. (2007) reported that barley leaf tea had antioxidant effects due to high DPPH radical scavenging activity.

The objective of this study was to evaluate the effects of lotus leaf powder and barley leaf powder in raw minced pork during chilled storage $\left(4 \pm 1^{\circ} \mathrm{C}\right)$ for $10 \mathrm{~d}$.

\section{Materials and Methods}

\section{Preparation of meat and samples}

Fresh pork hams, weighing 6.5-7.0 kg each, were purchased from a pilot plant at Konkuk University, Korea at $48 \mathrm{~h}$ postmortem. The pork back fat was also collected from the slaughter house. All subcutaneous and intermuscular fat and visible connective tissues were removed from the fresh ham muscles.

The raw minced pork was prepared by the following formulation and process: $73.5 \%$ lean pork meat, $20 \%$ pork back fat, $5 \%$ ice, and $1.5 \%$ salt. The lean pork meat and pork back fat were ground through a $3 \mathrm{~mm}$ plate and then the ice and salt were added. The lotus leaf powder and hot-air-dried barley leaf powder was added at levels of $0 \%$ (Control (-), 0.1\% (LP1 and BP1), and 0.5\% (LP2 and BP2), and added $0.01 \%$ BHT (Control $(+)$ ). These percentages were based on the control formula weight. Samples were hand mixed for $10 \mathrm{~min}$. Then, the raw minced pork meat was anaerobically packed in $\mathrm{PE} /$ nylon film bags and stored for maximum of $10 \mathrm{~d}$ at $4 \pm 1^{\circ} \mathrm{C}$.

\section{pH values}

The $\mathrm{pH}$ values of samples were determined with a $\mathrm{pH}$ meter (Model 340, Mettler-Toledo GmbH, Switzerland). The $\mathrm{pH}$ of the raw minced pork was measured after blending $5 \mathrm{~g}$ of sample with $20 \mathrm{~mL}$ of distilled water for
$60 \mathrm{~s}$ in a homogenizer (Ultra-Turrax SK15, Janke \& Kunkel, Germany).

\section{Instrumental color evaluations}

The instrumental color analyses of the raw pork patties were conducted as follows. The color measurements were taken with a colorimeter (Chroma meter CR-210, Minolta, Japan; illuminate $\mathrm{C}$, calibrated with a white standard plate $\mathrm{CIE} \mathrm{L}^{*}=97.83$, CIE a $\left.{ }^{*}=-0.43, \mathrm{CIE}^{*}=+1.98\right)$, consisting of an $8 \mathrm{~mm}$ diameter measuring area and a $50 \mathrm{~mm}$ diameter illumination area. The color values (CIE L*, ${ }^{*}$, and $b^{*}$ ) were measured on the sample surfaces and data were taken in triplicate for each sample.

\section{Thiobarbituric acid reaction substance (TBARS) values}

Lipid oxidation was assessed in triplicate by the 2thiobarbituric acid (TBA) method of Tarladgis et al. (1960) with minor modifications. Fifty $\mathrm{mL}$ of distilled water was added to $10 \mathrm{~g}$ sample prior to homogenizing with a homogenizer (AM-7, Nihonseiki Kaisha Ltd., Japan) at 10,000 rpm for $2 \mathrm{~min}$. The cup used for blending was washed with an additional $47.5 \mathrm{~mL}$ of distilled water, which was added to the same distillation flask with $2.5 \mathrm{~mL} 4 \mathrm{~N} \mathrm{HCl}$ and a few drops of an antifoam agent, silicone o/w (KMK-73, Shin-Etsu Silicone Co., Ltd., Korea). The mixture was distilled and $50 \mathrm{~mL}$ distillate was collected. Five $\mathrm{mL}$ of $0.02 \mathrm{M} 2$-thiobarbituric acid in $90 \%$ acetic acid (TBA reagent) was added to a vial containing $5 \mathrm{~mL}$ of the distillate and mixed well. The vials were capped and heated in a boiling water bath for 30 min to develop the chromogen and cooled to room temperature. The absorbance was measured at $538 \mathrm{~nm}$, against a blank prepared with distilled water $(5 \mathrm{~mL})$ and TBAreagent $(5 \mathrm{~mL})$, using a UV/VIS spectrophotometer (Libra S22, Biochrom Ltd., England). TBARS values were calculated by multiplying the absorbance by $73 \%$, the recovery of the standard from meat, resulting in a $\mathrm{K}$ value of 7.8. The TBA values were calculated as mg malonaldehyde (MA)/kg sample.

TBA $($ mg MA/sample $\mathrm{kg})=$ OD value $\times 7.8$

\section{Peroxide values (PV) and free fatty acids (FFA)}

Lipids from the samples were extracted by the method of Folch (Floch et al., 1957) using the chloroform:methanol solvent system $(2: 1)$. The lipid extracts were evaporated and concentrated with a rotary evaporator (Rotary evaportater N-1000, EYELA, Japan). The peroxide val- 
ues (PV) of the lipids extracted from the samples were determined by AOAC (1999), and calculated as follows: $\mathrm{PV}(\mathrm{meq} / \mathrm{kg})=(\mathrm{S}-\mathrm{B}) \times \mathrm{F} \times \mathrm{N} \times 1000 / \mathrm{W}[\mathrm{S}$, titration amount of sample; B, titration amount of blank; $\mathrm{F}$, titer of $0.01 \mathrm{~N}$ sodium thiosulfate; $\mathrm{N}$, normality of sodium thiosulfate; $\mathrm{W}$, sample weight $(\mathrm{g})]$. The results are expressed as milliequivalent peroxide $\mathrm{O}_{2} / \mathrm{kg}$ meat. The free fatty acids (FFA) values of the extracted lipids were determined by AOCS (1987), and calculated as follows: FFA $(\%)=(\mathrm{S}-\mathrm{B}) \times \mathrm{N} \times 28.2 / \mathrm{W}[\mathrm{S}$, titration amount of sample; $\mathrm{B}$, titration amount of blank; F, titer of $0.01 \mathrm{~N} \mathrm{KOH}$; N, normality of $\mathrm{KOH}$; W, sample weight $(\mathrm{g})]$.

\section{Microbiological analysis}

A $5 \mathrm{~g}$ aliquot of each sample was aseptically transferred into a sterile stomacher bag at each respective sampling interval and $45 \mathrm{~mL}$ of sterile distilled water was added. The sample was then evenly mixed in the stomacher (Masticator-Paddle-Blender, IUL Instrument, Spain) for 2 min at normal speed and aliquots were plated out directly at 1:10 dilution in sterile distilled water. After serially diluting each sample in sterile distilled water, $0.1 \mathrm{~mL}$ portions were separately plated onto plates. The total bacterial count was determined on plate count agar (PCA, Difco, USA) at $35^{\circ} \mathrm{C}$ for $48 \mathrm{~h}$. Microbial colonies were counted and expressed as $\log _{10} \mathrm{CFU} / \mathrm{g}$ pork meat.

\section{Statistical analysis}

Analysis of variance was performed on all the variables measured using the General Linear Model (GLM) procedure of the SAS statistical package (SAS Institute, Inc., 1999). Duncan's multiple range test $(p<0.05)$ was used to determine the differences between treatment means.

\section{Results and Discussion}

\section{pH evaluations}

The evaluated $\mathrm{pH}$ values in the raw minced pork containing various powders and BHT are presented in Table 1. These values ranged from 5.52-5.70. The additions of the various powders resulted in increased $\mathrm{pH}$ on day 1 and 4. Furthermore, a dramatic decrease in $\mathrm{pH}(p<0.05)$ was observed on storage day 10 in the samples with LP and BP. However, $\mathrm{pH}$ values were not affected by storage time as reported by Park and Chin (2007). The $\mathrm{pH}$ values of control $(+)$ increased during $10 \mathrm{~d}$. McCarthy et al. (2001) demonstrated improvements in the $\mathrm{pH}$ values of pork patties with added BHA/BHT, ginseng, and rosemary, and Lo Fiego et al. (2004) demonstrated that levels of dietary vitamin $\mathrm{C}$ caused increases of $\mathrm{pH}$ values.

\section{Instrumental color evaluations}

Meat color relies on concentrations of myoglobin and hemoglobin, thus the chemical state of meat. Moreover, levels of added lean meat or fat can affect the color of meat products (Song et al., 2002). The color of meat products is an important criterion of judgment for consumer purchases. Georgantelis et al. (2007) found that meat color was affected by storage temperature, packing method, muscle type, and the color of additives. There were effects in terms of the color of the raw minced pork by the lotus leaf and barley leaf powders during 1,4 , and $7 \mathrm{~d}$ under chilled storage conditions (Table 2). The redness values of control (-) were highest during the $10 \mathrm{~d}$. This agrees with the results of Choe et al. (2008) who found that the redness values of pork patties containing a medicinal herb extract mix were lower than those of a control, and Hayes et al. (2010) reported that raw minced

Table 1. Effects of lotus leaf and barley leaf powder on $\mathrm{pH}$ in raw minced pork during chilled storage for $10 \mathrm{~d}$

\begin{tabular}{lcccc}
\hline \hline & \multicolumn{4}{c}{ Storage time (d) } \\
\cline { 2 - 5 } Treatment ${ }^{1)}$ & 1 & 4 & 7 & 10 \\
\hline Control (-) & $5.63 \pm 0.01^{\mathrm{Ba}}$ & $5.64 \pm 0.02^{\mathrm{Da}}$ & $5.65 \pm 0.01^{\mathrm{BCa}}$ & $5.65 \pm 0.01^{\mathrm{Ba}}$ \\
LP1 & $5.64 \pm 0.05^{\mathrm{ABab}}$ & $5.67 \pm 0.01^{\mathrm{BCa}}$ & $5.61 \pm 0.02^{\mathrm{Dab}}$ & $5.52 \pm 0.03^{\mathrm{Db}}$ \\
LP2 & $5.65 \pm 0.01^{\mathrm{ABa}}$ & $5.65 \pm 0.02^{\mathrm{CDa}}$ & $5.64 \pm 0.01^{\mathrm{Ca}}$ & $5.48 \pm 0.01^{\mathrm{Eb}}$ \\
BP1 & $5.63 \pm 0.02^{\mathrm{Bb}}$ & $5.67 \pm 0.02^{\mathrm{Ba}}$ & $5.66 \pm 0.01^{\mathrm{Ba}}$ & $5.59 \pm 0.01^{\mathrm{Cc}}$ \\
BP2 & $5.68 \pm 0.01^{\mathrm{Ab}}$ & $5.70 \pm 0.01^{\mathrm{Aa}}$ & $5.70 \pm 0.01^{\mathrm{Aa}}$ & $5.59 \pm 0.01^{\mathrm{Cc}}$ \\
Control (+) & $5.63 \pm 0.01^{\mathrm{Bb}}$ & $5.66 \pm 0.01^{\mathrm{CDa}}$ & $5.66 \pm 0.01^{\mathrm{Ba}}$ & $5.67 \pm 0.01^{\mathrm{Aa}}$ \\
\hline
\end{tabular}

All values are mean $\pm \mathrm{SD}$ of three replicates.

${ }^{A-E}$ Means within columns with different superscript letters are significantly different $(p<0.05)$.

${ }^{\mathrm{a}-\mathrm{c}}$ Means within rows with different superscript letters are significantly different $(p<0.05)$.

${ }^{1)}$ Control (-), Raw minced pork without antioxidant powder; LP1, Raw minced pork with $0.1 \%$ lotus leaf powder; LP2, Raw minced pork with $0.5 \%$ lotus leaf powder; BP1, Raw minced pork with $0.1 \%$ barley leaf powder; BP2, Raw minced pork with $0.5 \%$ lotus leaf powder; Control (+), Raw minced pork with $0.01 \%$ BHT 
Table 2. Effects of lotus leaf and barley leaf powder on instrument color in raw minced pork during chilled storage for $10 \mathrm{~d}$

\begin{tabular}{|c|c|c|c|c|c|c|}
\hline "Treatment ${ }^{1)}$ & $\mathrm{CIE} \mathrm{L}_{\text {day } 1}^{*}$ & 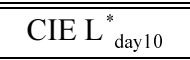 & $\mathrm{CIE} \mathrm{a}_{\text {day } 1}^{*}$ & CIE a ${ }_{\text {day10 }}^{*}$ & $\mathrm{CIE} \mathrm{b}_{\text {day1 }}{ }^{2}$ & $\mathrm{CIE} \mathrm{b}_{\text {day10 }}^{*}$ \\
\hline Control (-) & $61.23 \pm 0.03^{\mathrm{ABa}}$ & $58.12 \pm 0.98^{\mathrm{Cb}}$ & $13.28 \pm 0.28^{\mathrm{Aa}}$ & $7.88 \pm 0.25^{\mathrm{Ab}}$ & $13.61 \pm 0.64^{\mathrm{Eb}}$ & $15.82 \pm 0.16^{\mathrm{Da}}$ \\
\hline LP1 & $61.82 \pm 0.89^{\mathrm{Aa}}$ & $59.51 \pm 0.66^{\mathrm{Bb}}$ & $10.78 \pm 0.86^{\mathrm{Ba}}$ & $6.31 \pm 0.41^{\mathrm{Bb}}$ & $15.11 \pm 0.26^{\mathrm{Db}}$ & $16.80 \pm 0.34^{\mathrm{Ca}}$ \\
\hline LP2 & $58.62 \pm 0.97^{\mathrm{Ca}}$ & $54.25 \pm 0.69^{\mathrm{Eb}}$ & $6.89 \pm 0.66^{\mathrm{Ca}}$ & $2.68 \pm 0.74^{\mathrm{Db}}$ & $17.7 \pm 0.22^{\mathrm{Bb}}$ & $18.97 \pm 0.38^{\mathrm{Ba}}$ \\
\hline BP1 & $60.10 \pm 0.61^{\mathrm{BCa}}$ & $58.07 \pm 0.65^{\mathrm{Cb}}$ & $6.65 \pm 0.08^{\mathrm{Ca}}$ & $3.98 \pm 0.31^{\mathrm{Cb}}$ & $16.02 \pm 0.11^{\mathrm{Cb}}$ & $17.61 \pm 0.17^{\mathrm{Ba}}$ \\
\hline BP2 & $56.30 \pm 0.80^{\mathrm{Da}}$ & $56.12 \pm 0.56^{\mathrm{Db}}$ & $-1.49 \pm 0.11^{\mathrm{Da}}$ & $-2.03 \pm 0.20^{\mathrm{Eb}}$ & $20.3 \pm 0.54^{\mathrm{Ab}}$ & $21.81 \pm 0.08^{\mathrm{Aa}}$ \\
\hline Control $(+)$ & $60.30 \pm 0.45^{\mathrm{ABa}}$ & $61.94 \pm 0.89^{\mathrm{Ab}}$ & $11.27 \pm 0.35^{\mathrm{Ba}}$ & $8.01 \pm 0.26^{\mathrm{Ab}}$ & $13.41 \pm 0.34^{\mathrm{Eb}}$ & $14.99 \pm 0.18^{\mathrm{Ca}}$ \\
\hline
\end{tabular}

All values are mean $\pm \mathrm{SD}$ of three replicates.

A-E Means within columns with different superscript letters are significantly different $(p<0.05)$.

${ }^{\mathrm{a}-\mathrm{b}}$ Means within rows with different superscript letters are significantly different $(p<0.05)$.

${ }^{1)}$ Control (-), Raw minced pork without antioxidant powder; LP1, Raw minced pork with $0.1 \%$ lotus leaf powder; LP2, Raw minced pork with $0.5 \%$ lotus leaf powder; BP1, Raw minced pork with $0.1 \%$ barley leaf powder; BP2, Raw minced pork with $0.5 \%$ lotus leaf powder; Control (+), Raw minced pork with $0.01 \%$ BHT

beef patties with added sesamol extracts had lower $(p<0.05) \mathrm{a}^{*}$ values than a control. It was also found that meat samples with added BHT had their highest redness values at 1 and $4 \mathrm{~d}$ of storage (Prasetyo et al., 2008). The BP2 treatment had the lowest $(p<0.05)$ redness values. Also, redness values were significantly lower with a longer storage period. Similarly, it was found that increasing storage time resulted in reduced redness of ground beef (Ismail et al., 2008). On the other hand, the treatment of lotus leaf and barley leaf powder appeared to delay discoloration according to $\mathrm{a}^{*}$ values relative to control (-). This result indicates that lotus leaf and barley leaf powder may have antioxidant activity by reducing the formation of metmyoglobin.

Lightness significantly decreased $(p<0.05)$ with increasing storage time in the raw ground pork except for control (+). Increases in LP and BP content resulted in decreases of $\mathrm{L}^{*}$ and $\mathrm{a}^{*}$ values and increases of $\mathrm{b}^{*}$ values in the raw minced pork, respectively. However, previous work determined that $\mathrm{L}^{*}$ values rose by adding colorfico to raw chicken patties (Castro et al., 2011). Furthermore, the yellowness of fermented sausage was increased by the addition of hazelnut oil (Yildiz-Turp and Serdaroðlu, 2008).

\section{TBARS values}

TBARS values were determined by the production of malondialdehyde in combination with TBARS and detected at $538 \mathrm{~nm}$. The TBARS values demonstrated effects of the lotus leaf and barley leaf powder in the raw minced pork during chilled storage for $10 \mathrm{~d}$ (Table 3). The TBARS values of the raw minced pork ranged from 0.16 to $0.60 \mathrm{mg}$ MA $/ \mathrm{kg}$ of meat. TBARS values significantly increased with increasing storage time. Sohn et al. (2009) found that lipid oxidation increased up to $7 \mathrm{~d}$ with increasing storage time in ground beef containing $\alpha$-tocopherol. However, TBARS values were significantly decreased in both raw pork patties with green tea leaf extract and raw ground goat meat with added pomegran-

Table 3. Effects of lotus leaf and barley leaf powder on TBARS values (mg/MA/kg meat) in raw minced pork during chilled storage for $10 \mathrm{~d}$

\begin{tabular}{|c|c|c|c|c|}
\hline \multirow{2}{*}{ Treatment $^{1)}$} & \multicolumn{4}{|c|}{ Storage time $(\mathrm{d})$} \\
\hline & 1 & 4 & 7 & 10 \\
\hline Control (-) & $0.25 \pm 0.32^{\mathrm{Ad}}$ & $0.38 \pm 0.12^{\mathrm{Ac}}$ & $0.51 \pm 0.39^{\mathrm{Ab}}$ & $0.60 \pm 0.29^{\mathrm{Aa}}$ \\
\hline LP1 & $0.18 \pm 0.32^{\mathrm{Dd}}$ & $0.20 \pm 0.40^{\mathrm{Dc}}$ & $0.20 \pm 0.32^{\mathrm{Ec}}$ & $0.27 \pm 0.12^{\mathrm{Eb}}$ \\
\hline LP2 & $0.16 \pm 0.14^{\mathrm{Ed}}$ & $0.18 \pm 0.67^{\mathrm{Ec}}$ & $0.21 \pm 0.18^{\mathrm{Eb}}$ & $0.22 \pm 0.23^{\mathrm{Fb}}$ \\
\hline BP1 & $0.22 \pm 0.61^{\mathrm{Ce}}$ & $0.30 \pm 0.12^{\mathrm{Bd}}$ & $0.33 \pm 0.17^{\mathrm{Cc}}$ & $0.36 \pm 0.52^{\mathrm{Cb}}$ \\
\hline BP2 & $0.24 \pm 0.36^{\mathrm{Be}}$ & $0.31 \pm 0.08^{\mathrm{Bd}}$ & $0.42 \pm 0.32^{\mathrm{Bc}}$ & $0.43 \pm 0.22^{\mathrm{Bc}}$ \\
\hline Control (+) & $0.19 \pm 0.27^{\mathrm{De}}$ & $0.23 \pm 0.36^{\mathrm{Cd}}$ & $0.28 \pm 0.06^{\mathrm{Dc}}$ & $0.31 \pm 0.36^{\mathrm{Db}}$ \\
\hline
\end{tabular}

All values are mean $\pm \mathrm{SD}$ of three replicates.

${ }^{\text {A-F }}$ Means within columns with different superscript letters are significantly different $(p<0.05)$.

${ }^{\mathrm{a}-\mathrm{e}}$ Means within rows with different superscript letters are significantly different $(p<0.05)$.

${ }^{1)}$ Control (-), Raw minced pork without antioxidant powder; LP1, Raw minced pork with $0.1 \%$ lotus leaf powder; LP2, Raw minced pork with $0.5 \%$ lotus leaf powder; BP1, Raw minced pork with $0.1 \%$ barley leaf powder; BP2, Raw minced pork with $0.5 \%$ lotus leaf powder; Control (+), Raw minced pork with $0.01 \%$ BHT 


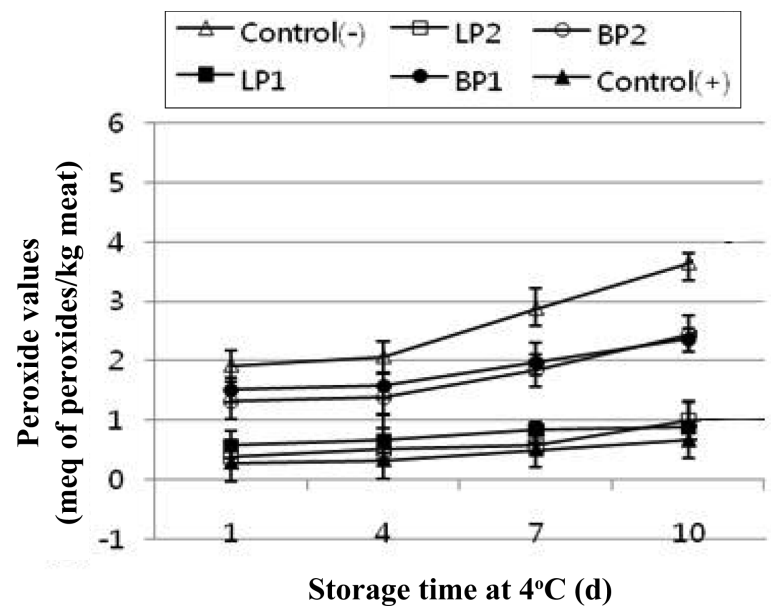

Fig. 1. Effects of lotus leaf and barley leaf powder on peroxide values (meq of peroxides/kg meat) of raw minced pork during chilled storage for $\mathbf{1 0}$ d. All values are mean $\pm \mathrm{SD}$ of three replicates.

ate seed powder (Devatkal and Naveena, 2010; Jo et al., 2003). In the present study, the TBARS values of control $(-)$ were highest $(p<0.05)$ while those of the treatments with LP were lowest $(p<0.05)$ during the entire storage period. The treatments with LP resulted in decreased $(p<0.05)$ TBARS values as compared to the treatments with BP. The raw minced pork containing added BP had lower TBARS compared to control (-) during storage. In the raw minced pork with LP, lipid oxidation inhibition activity was concentration-dependent, whereas lipid oxidation inhibition activity was not dependent on the concentration of $\mathrm{BP}$ in the raw minced pork. The results of this study indicate that the additions of lotus leaf and barley leaf powder had improved effects $(p<0.05)$ in terms of inhibiting lipid oxidation in raw minced pork. Hernández-Hernández et al. (2009) used rosemary and oregano extracts in order to diminish lipid oxidation in raw pork batters. Greene and Cumuze (1982) found that a TBARS range of $0.6-2.0 \mathrm{mg} / \mathrm{kg}$ of meat induced off-flavor according to trained panelists.

\section{PV}

PV measure the concentration of hydroperoxides produced at early stages of oxidation. PV ranging from 20 to $40 \mathrm{meq} / \mathrm{kg}$ of meat have indicated rancidity of meat products (Economou et al., 1991). The peroxide values of the raw minced pork containing lotus leaf or barley leaf powder are shown in Fig. 1. PV ranged from 0.28 to 3.64 meq of peroxides $/ \mathrm{kg}$ of raw minced pork at chilled storage for $10 \mathrm{~d}$. Georgantelis (2007) reported that beef burgers had POV of 0.24-2.69 meq of peroxides $/ \mathrm{kg}$ of fat during 180 $\mathrm{d}$ of freezing storage. In the present study, increases in PV depended on increases in the storage time of raw minced pork. After $4 \mathrm{~d}$ of chilled storage, PV significantly increased. This may be due to the catalysis of intracellular compounds, in which cell structures were degraded by $\mathrm{NaCl}$ and processing. The treatments containing lotus leaf and barley leaf powder represented lower $(p<0.05) \mathrm{PV}$ than control (-) during the entire storage period. The greatest differences in PV values were found between control (-) and the LP1 raw minced pork, which had the best effect toward lipid oxidation on day 10. A similar consequence was previously shown in liver sausage without/with rosemary extract on day 3 at $4^{\circ} \mathrm{C}$ (Waszkowiak and Dolata, 2007). The reduction of PV in raw minced pork containing LP and BP may be due to the presence of a number of phenolic compounds.

\section{FFA}

FFA in the raw minced pork containing LP and BP ranged from 1.82 to $3.60 \%$. FFA significantly $(p<0.05)$ increased with increasing storage days in all treatments (Table 4). Kwak and Kang (2000) reported that free fatty acids increased in Korean beef during storage. Dempster et al. (1985) demonstrated that increased FFA resulted from the decomposition of triglycerides and phospholipids in meat products. These changes by action of tissue enzymes can cause quality deterioration of products. There were no significant differences in FFA among all treatments on days 1 and 4. However, the additions of LP and BP to the raw minced pork resulted in slightly lower FFA on day 1 and 4. The LP2 sample indicated antioxidants effectiveness by having the lowest FFA among the entire treatments.

\section{Microbiological analysis}

The microbiological analysis results of the raw minced pork containing LP and BP during $10 \mathrm{~d}$ of storage are shown in Table 5. No significant differences were found in total bacterial counts of all treatments, except LP2 on day 1. Allen and Cornforth (2010) reported that the total aerobic plate counts of ground beef patties without/with eugenol and rosmarinic acid were not significantly different. The additions of LP and BP to the raw minced pork significantly decreased $(p<0.05)$ total bacterial counts after $4 \mathrm{~d}$ of storage compared to control (-). At storage day 10, LP1 and LP2 showed significantly inhibited $(p<0.05)$ total bacterial counts by $\log 4.28 \mathrm{CFU} / \mathrm{g}$ and $\log$ 4.16 CFU/g, respectively, compared to control (-). Previous research has shown that a medicinal herb extract mix 
Table 4. Effects of lotus leaf and barley leaf powder on FFA in raw minced pork during chilled storage for $10 \mathrm{~d}$

\begin{tabular}{lccc}
\hline \hline Treatment $^{1)}$ & \multicolumn{1}{c}{ Storage time $(\mathrm{d})$} \\
\cline { 2 - 4 } & 1 & 4 & 7 \\
\hline Control (-) & $2.16 \pm 0.15^{\mathrm{Ad}}$ & $2.29 \pm 0.05^{\mathrm{Ac}}$ & $2.96 \pm 0.08^{\mathrm{Ab}}$ \\
LP1 & $2.01 \pm 0.43^{\mathrm{ABc}}$ & $2.06 \pm 0.37^{\mathrm{ABb}}$ & $2.41 \pm 0.01^{\mathrm{BCc}}$ \\
LP2 & $1.82 \pm 0.20^{\mathrm{Bc}}$ & $1.93 \pm 0.20^{\mathrm{Bc}}$ & $2.25 \pm 0.02^{\mathrm{Cb}}$ \\
BP1 & $2.09 \pm 0.20^{\mathrm{ABc}}$ & $2.22 \pm 0.15^{\mathrm{Ac}}$ & $2.58 \pm 0.30^{\mathrm{Bb}}$ \\
BP2 & $2.05 \pm 0.03^{\mathrm{ABd}}$ & $2.30 \pm 0.05^{\mathrm{Ac}}$ & $2.05 \pm 0.04^{\mathrm{Ca}}$ \\
Control (+) & $2.03 \pm 0.08^{\mathrm{ABd}}$ & $2.20 \pm 0.08^{\mathrm{Ac}}$ & $2.90 \pm 0.16^{\mathrm{CDa}}$ \\
\hline
\end{tabular}

All values are mean \pm SD of three replicates.

A-E Means within columns with different superscript letters are significantly different $(p<0.05)$.

${ }^{\text {a-d }}$ Means within rows with different superscript letters are significantly different $(p<0.05)$.

${ }^{1)}$ Control (-), Raw minced pork without antioxidant powder; LP1, Raw minced pork with 0.1\% lotus leaf powder; LP2, Raw minced pork with $0.5 \%$ lotus leaf powder; BP1, Raw minced pork with $0.1 \%$ barley leaf powder; BP2, Raw minced pork with $0.5 \%$ lotus leaf powder; Control (+), Raw minced pork with $0.01 \%$ BHT

Table 5. Effects of lotus leaf and barley leaf powder on total aerobic counts in raw minced pork during chilled storage for $10 \mathrm{~d}$

\begin{tabular}{|c|c|c|c|c|}
\hline \multirow{2}{*}{ Treatment $^{1)}$} & \multicolumn{4}{|c|}{ Storage time $(\mathrm{d})$} \\
\hline & 1 & 4 & 7 & 10 \\
\hline Control (-) & $2.64 \pm 0.03^{\mathrm{Ad}}$ & $2.89 \pm 0.02^{\mathrm{Ac}}$ & $4.03 \pm 0.03^{\mathrm{Ab}}$ & $5.23 \pm 0.01^{\mathrm{Aa}}$ \\
\hline LP1 & $2.56 \pm 0.02^{\mathrm{ABc}}$ & $2.79 \pm 0.08^{\mathrm{Ab}}$ & $3.92 \pm 0.011^{\mathrm{Ca}}$ & $4.28 \pm 0.02^{\mathrm{Da}}$ \\
\hline LP2 & $1.89 \pm 0.21^{\mathrm{Bd}}$ & $2.41 \pm 0.01^{\mathrm{Cc}}$ & $3.78 \pm 0.050^{\mathrm{Db}}$ & $4.16 \pm 0.01^{\mathrm{Ea}}$ \\
\hline BP1 & $2.38 \pm 0.10^{\mathrm{Ad}}$ & $2.84 \pm 0.08^{\mathrm{Ac}}$ & $3.98 \pm 0.019^{\mathrm{Bb}}$ & $4.41 \pm 0.08^{\mathrm{Ca}}$ \\
\hline BP2 & $2.51 \pm 0.12^{\mathrm{Ad}}$ & $2.64 \pm 0.01^{\mathrm{Bc}}$ & $3.96 \pm 0.01^{\mathrm{Bb}}$ & $4.51 \pm 0.05^{\mathrm{Ba}}$ \\
\hline Control (+) & $2.20 \pm 0.13^{\mathrm{ABd}}$ & $2.38 \pm 0.14^{\mathrm{Cc}}$ & $3.97 \pm 0.04^{\mathrm{Bb}}$ & $4.48 \pm 0.20^{\mathrm{BCa}}$ \\
\hline
\end{tabular}

All values are mean \pm SD of three replicates.

${ }^{\text {A-E }}$ Means within columns with different superscript letters are significantly different $(p<0.05)$.

${ }^{\mathrm{a}-\mathrm{d}}$ Means within rows with different superscript letters are significantly different $(p<0.05)$.

${ }^{1)}$ Control (-), Raw minced pork without antioxidant powder; LP1, Raw minced pork with $0.1 \%$ lotus leaf powder; LP2, Raw minced pork with $0.5 \%$ lotus leaf powder; BP1, Raw minced pork with $0.1 \%$ barley leaf powder; BP2, Raw minced pork with $0.5 \%$ lotus leaf powder; Control (+), Raw minced pork with $0.01 \%$ BHT

(1\%) inhibited microorganism growth in pork patties compared to a control according to a log $1 \mathrm{CFU} / \mathrm{g}$ difference at $10 \mathrm{~d}$ of chilled storage (Choe et al., 2008). The BP2 sample had higher inhibition activity of its microorganism counts than control (+), but the difference was not significant.

\section{Acknowledgement}

This study was supported by the Ministry of Agriculture and Forestry (808010-3-1-2), Republic of Korea. The authors also partially supported by the Brain Korean 21 (BK 21) Project from Ministry of Education and Human Resources Development.

\section{References}

1. Allen, K. and Cornforth, D. (2010) Comparison of spicederived antioxidants and metal chelators on fresh beef color stability. Meat Sci. 85, 613-619.

2. AOCS (1987). Official and tentative methods of the American Oil Chemist's Society. 3rd ed, American Oil Chemist's Society, Champaign, IL, USA.

3. Arimoto, T., Ichinose, T., Yoshikawa, T., and Shibamoto, T. (2000) Effect of the natural antioxidant 2-O-glycosylisovitexin on superoxide and hydroxyl radical generation. Food Chem. Toxicol. 38, 849-852.

4. Asghar, A., Gray, J. I., Buckley, D. J., and Pearson, A. M. (1998) Perspectives on warmed-over flavor. Food Technol. 42, 102-108.

5. Bastida, S., Sanchez-Muniz, F. J., Olivero, R., Perez-Olleros, L., Ruiz-Roso, B., and Jimenez-Colmenero, F. (2009) Antioxidant activity of Carob fruit extracts in cooked pork meat systems during chilled and frozen storage. Food Chem. 116, 748-754.

6. Bozkurt, H. (2006) Utilization of natural antioxidants: Green tea extract and Thymbra spicata oil in Turkish dry-fermented sausage. Meat Sci. 73, 442-450.

7. Brannan, R. G. (2008) Effect of grape seed extract on physicochemical properties of ground, salted chicken thigh meat during refrigerated storage at different relative humidity lev- 
els. Food Chem. 73, 36-38.

8. Castro, W. F., Mariutti, L. R. B., and Bragagnolo, N. (2011) The effects of colorifico on lipid oxidation, colour and vitamin $\mathrm{E}$ in raw and grilled chicken patties during frozen storage. Food Chem. 124, 126-131.

9. Choe, J. H., Jang, A., Choi, J. H., Choi, Y. S., Han, D. J., Kim, H. Y., Lee, M. A., Kim, H. W., and Kim, C. J. (2010) Antioxidant activities of lotus leaves (Nelumbo nucifera) and barley leaves (Hordeum vulgare) extracts. Food Sci. Biotechnol. 19, 831-836.

10. Choe, J. H., Jang, A., Lee, B. D., Liu, X. D., Song, H. P., and Jo, C. (2008) Antioxidant and antimicrobial effects of medicinal herb extract mix in pork patties during cold storage. Korean J. Food Sci. Ani. Resour. 28, 122-129.

11. De Oliveria, O. C., Valentim, I. B., Silva, C. A., Bechara, E. J. H., De Barros, M. P., Mano, C. M., and Goulart, M. O. F. (2009) Total phenolic content and free radical scavenging activities of methanolic extract powders of tropical fruit residues. Food Chem. 115, 469-475.

12. Dempster, J. F., Hawrysh, Z. J., Shand, P., Lahola-Chomiak, L., and Corletto, L. (1985) Effect of low dose irradiation (radurisation) on the shelf life of beef burgers stored at $3^{\circ} \mathrm{C}$. Food Technol. 20, 145-154.

13. Devatkal, S. K. and Naveena, B. M. (2010) Effect of salt, kinnow and pomegranate fruit by-product powders on color and oxidative stability of raw ground goat meat during refrigerated storage. Meat Sci. 85, 306-311.

14. Economou, K. D., Oreopoulou, V., and Thomopoulos, C. D. (2991) Antioxidant activity of some plant extract of the family labiates. J. Am. Oil Chem. Soc. 68, 109-113.

15. Folch, J., Lee, M. and Stanley, S. G. H. (1957) A simple method for the isolation and purification of total 348 lipids from animal tissues. J. Biol. Chem. 226, 497-509.

16. Ganhão, R., Morcuende, D., and Estévez M. (2010) Protein oxidation in emulsified cooked burger patties with added fruit extracts: Influence on colour and texture deterioration during chill storage. Meat Sci. 85, 402-409.

17. Georgantelis, D., Blekas, G., Katikou, P., Ambrosiadis, I., and Fletouris, D. J. (2007) Effect of rosemary extract, chitosan and $\alpha$-tocopherol on lipid oxidation and colour stability during frozen storage of beef burgers. Meat Sci. 75, 256-264.

18. Greene, B. A. and Cumuze, T. H. (1982) Relationship between TBA numbers and inexperienced panelists. Assessments of oxidized flavour in cooked beef. J. Food Sci. 47, 52-58.

19. Han, J. and Rhee, K. S. (2005) Antioxidant properties of selected oriental non-culinary/nutraceutical herb extracts as evaluated in raw and cooked meat. Meat Sci. 70, 2533.

20. Hernández-Hernández, E., Ponce-Alquicira, E., JaramilloFlores, M. E., and Guerrero-Legarreta, I. (2009) Antioxidant effect rosemary (Rosmarinus officinalis L.) and oregano (Origanum vulgare L.) extracts on TBARS and colour of model raw pork batters. Meat Sci. 81, 410-417.

21. Ismail, H. A., Lee, E. J., Ko, K. Y., and Ahn, D. U. (2008) Effects of aging time and natural antioxidants on the color, lipid oxidation and volatiles of irradiated ground beef. Meat
Sci. 80, 582-591.

22. Jang, J. H., Choi, H. S., Cheong, H. S., and Kang, O. J. (2007) A comparison of the antioxidant activity of barley leaf tea and green tea according to leaching conditions in distilled water. Korean J. Food Cookery Sci. 23, 165-172.

23. Jo, C., Son, J. H., Son, C. B., and Byun, M. W. (2003) Functional properties of raw and cooked pork patties with added irradiated, freeze-dried green tea leaf extract powder during storage at $4^{\circ} \mathrm{C}$. Meat Sci. 64, 13-17.

24. Kwak, H. J. and Kang, I. J. (2000) Irradiation of Korean beef for the improvement of hygienic and quality preservation. Korean J. Food Sci. Technol. 2, 363-372.

25. Lee, K. S., Kim, M. G., and Lee, K. Y. (2006a) Antioxidative activity of ethanol extract from lotus (Nelumbo nucifera) leaf. Korean J. Soc. Food Sci. Nutr. 35, 182-186.

26. Lee, K. S., Oh, C. S., and Lee, K. Y. (2006b) Antimicrobial effect of the fractions extracted from a lotus (Nelumbo nucifera) leaf. Korean J. Soc. Food Sci. Nutr. 35, 219-223.

27. Lee, Y. C., Son, J. Y., Kim, K. T., and Kim, S. S. (1994) Antioxidant activity of solvent extract isolated from barley leaves. Korean J. Food Nutr. 7, 332-337.

28. Lo Fiego, D. P., Santoro, P., Macchioni, P., Mazzoi, D., Piaton, F., Tasone, F., and De Leonibus, E. (2004) The effect of dietary supplementation of vitamin $\mathrm{C}$ and $\mathrm{E}$ on the $\alpha$-tocopherol content of muscles, liver and kidney, on the stability of lipids, and on certain meat quality parameters of the longissimus dorsi of rabbits. Meat Sci. 67, 319-327.

29. McCarthy, T. L., Kerry, J. P., Kerry, P. B., Lynch, P. B., and Buckely, D. J. (2001) Assessment of the antioxidant potential of natural food and plant extracts in fresh and previously frozen pork patties. Meat Sci. 57, 177-184.

30. Park, S. Y. and Jin, K. B. (2007) Evaluation of antioxidant activity in pork patties containing Bokbunja (Rubus coreanus) extract. Korean J. Food Sci. Ani. Resour., 27, 432-439.

31. Prasetyo, M., Chia, M., Hughey, C., and Were, L. M. (2008) Utilization of electron beam irradiated almond skin powder as a natural antioxidant in ground top round beef. J. Food Sci. 73, 1-6.

32. Rice-Evans, C. A., Miller, N. J., and Pagana, G. (1996) Structure-antioxidant activity relationship of flavonoids and phenolic acids. Free Radical Biol. Med. 20, 933-956.

33. SAS (1999) SAS/STAT Software for PC. Release 8.1, SAS Institute Inc., Cary, NC, USA.

34. Shahidi, F., Janita, P. K., and Wanasundara, P. D. (1992) Phenolic antioxidants. Crit. Rev. Food Sci. Nutr. 32, 67-103.

35. Shin, Y. J. (2007) Quality characteristics of fish paste containing lotus (Nelumbo nucifera) leaf powder. Korean $J$. Food Cookery Sci. 23, 947-953.

36. Sohn, S. H., Jang, A., Kim, J. K. Song, H. P., Kim, J. H., Lee, M., and Jo, C. (2009) Reduction of irradiation off-odor and lipid oxidation in ground beef by $\alpha$-tocopherol addition and the use of a charcoal pack. Radiat. Phys. Chem. 78, 141-146.

37. Song, H. I., Park, C. K., Nam, J. H., Yang, J. B., Kim, D. S., Moon, Y. H., and Jung, I. C. (2002) Quality and palatability of beef patty containing gums. J. Korean Soc. Food. Sci. Nutr. 31, 64-68. 
38. Devatkal, Suresh K. and Naveena, B. M. (2010) Effect of salt, kinnow and pomegranate fruit by-product powders on color and oxidative stability of raw ground goat meat during refrigerated storage. Meat Sci. 85, 306-311.

39. Waszkowiak, K. and Dolata, W. (2007) The application of collagen preparations as carriers of rosemary extract in the production of processed meat. Meat Sci. 75, 178-183.

40. Yildiz-Turp, G. and Serdaroðlu, M. (2008) Effect of replac- ing beef fat with hazelnut oil on quality characteristics of sucuk - A Turkish fermented sausage. Meat Sci. 78, 447-454.

41. Yoon, S. J. (2007) Quality characteristics of sulgitteok added with lotus leaf powder. Korean J. Food Cookery Sci. 23, 433442.

(Received 2010.11.15/Revised 1st 2010.12.15, 2nd 2010.12.30/ Accepted 2010.12.31) 